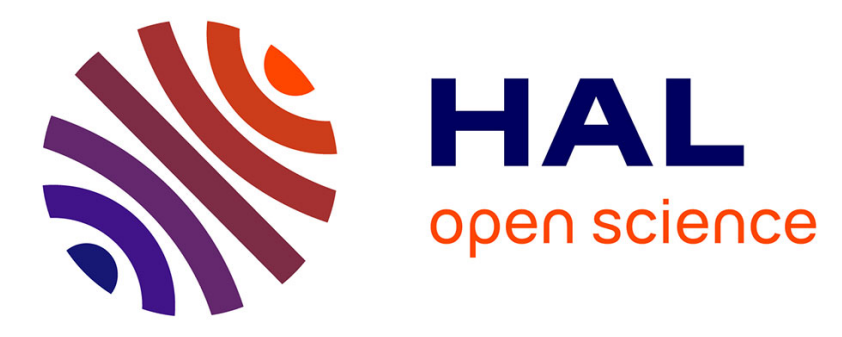

\title{
Towards a sport cluster model: the Ocean Racing Cluster in Brittany
}

Anna Gerke, Michel Desbordes, Geoff Dickson

\section{To cite this version:}

Anna Gerke, Michel Desbordes, Geoff Dickson. Towards a sport cluster model: the Ocean Racing Cluster in Brittany. European Sport Management Quarterly, 2015, 15 (3), pp.343-363. 10.1080/16184742.2015.1019535 . hal-01139821

\section{HAL Id: hal-01139821 \\ https://hal-audencia.archives-ouvertes.fr/hal-01139821}

Submitted on 7 Apr 2015

HAL is a multi-disciplinary open access archive for the deposit and dissemination of scientific research documents, whether they are published or not. The documents may come from teaching and research institutions in France or abroad, or from public or private research centers.
L'archive ouverte pluridisciplinaire HAL, est destinée au dépôt et à la diffusion de documents scientifiques de niveau recherche, publiés ou non, émanant des établissements d'enseignement et de recherche français ou étrangers, des laboratoires publics ou privés. 


\section{Title Page Information}

Title: Towards a sport cluster model: the Ocean Racing Cluster in Brittany

Authors: Anna Gerke, ${ }^{\mathrm{a} 1}$, Michel Desbordes $^{\mathrm{b}}$, Geoff Dickson $^{\mathrm{c}}$

a Audencia Nantes, School of Management, Department of Strategy, 8, Route de la Jonelière, 44312 Nantes Cedex 3, France, Phone +33 (0)2 4037 81 37, Email: agerke@audencia.com

${ }^{1}$ Part of this research was carried out by the first author while at the second and third author's institutions.

${ }^{\mathrm{b}}$ Paris-Sud University, Research Unit CIAMS - Complexity, Innovation and Motor and Sport Activities, Rue de Pierre de Coubertin, 91405 Orsay cedex, France, Phone: + 33 (0)1 691561 57, Email: michel.desbordes@u-psud.fr,

${ }^{\mathrm{c}}$ Auckland University of Technology, Faculty of Health and Environmental Sciences, Auckland 1020, New Zealand, Phone: +64 (0)9 9219999 ext. 7851, Email:

geoff.dickson@aut.ac.nz

Corresponding author: Anna Gerke, Audencia Nantes, School of Management, Department of Strategy, 8, Route de la Jonelière, 44312 Nantes Cedex 3, France, Phone +33 (0)2 403781 37, Email: agerke@audencia.com 


\title{
Towards a sport cluster model: the Ocean Racing Cluster in Brittany
}

\begin{abstract}
Research question: This research develops deductively a conceptual framework for the detection and analysis of sport clusters.

Research methods: We test this framework in the ocean racing cluster in Brittany, France. Primary data collection comprises 34 interviews and eight observations. Secondary data consisted of organisational information and archival data. Data were analysed with NVivo. Results and findings: The suggested framework consists of location-specific factors (LSF) that determine the development and sustainability of a sport cluster and 10 types of cluster organisations (CLOR) as typical members. We find that all suggested LSF are relevant. Some CLOR receive less attention than others. Shipyards, professional sport organisations, governing bodies, and marine equipment firms have key roles in the ocean racing cluster. Implications: The sport cluster framework is consistent and applicable to different contexts. Further sport cluster studies in different sports and countries are recommended to consolidate the concept and to enable practitioners to better understand and create sport clusters.
\end{abstract}

\section{Key words}

sport cluster, location-specific factor, cluster organisation, ocean racing 


\section{Towards a sport cluster model}

This research focuses on sport-equipment clusters and aims to understand clusters in the context of sport and sport-related industries. Clusters are evident within a variety of industrial contexts (Porter, 1998). Cluster theory emerged from the field of economic geography and its notion of industrial districts (Marshall, 2000). A cluster is a geographically denominated area characterised by a concentration of firms and associated organisations working in the same or interdependent industries. These organisations engage in simultaneous competition and cooperation (Porter, 1998; 2008).

Clusters have been studied in numerous different industrial contexts such as science and technology, craft and manufacturing, and art and leisure industries (Porter, 1998). While there are few conceptual articles on sport clusters (Hillairet, 2005; Shilbury, 2000), there is a larger number of empirical research articles (Chetty, 2004; Chetty \& Agndal, 2008; Glass \& Hayward, 2001; Kellett \& Russell, 2009; Parker \& Beedell, 2010; Richard, 2007; Sarvan et al., 2012; Stewart, Skinner, \& Edwards, 2008; Tristão, Oprime, Jugend, \& da Silva, 2013; Viljamaa, 2007). While all these articles make direct or indirect use of Porter's cluster concept, there is no common understanding of what exactly constitutes a sport cluster. This article aims at closing this research gap.

A sport cluster incorporates all organisations and industries in a particular geographical area that have an interest in the same sport or related sports as either buyer or seller (Shilbury, 2000). Sport refers to 'all forms of physical activity which, through casual or organised participation, aim at expressing or improving physical fitness and mental wellbeing, forming social relationships or obtaining results in competition at all levels' (Council of Europe Committee of Ministers, 2001, Art. 2). This definition is inclusive of recreational, competitive, professional, and amateur sport. Depending on research questions and empirical contexts in sport management research, scholars might want to take a more exclusive 
definition of sport. The sport cluster studied in this research focuses on competitive sport at professional and amateur levels.

In a deductive manner, we develop the concept of sport clusters as a framework for their detection and analysis. This framework is applied to the ocean racing cluster in Brittany, France. The framework is inductively complemented through themes that appear during data coding. The resulting framework consists of six location-specific factors (LSF) and ten types of cluster organisations (CLOR) that constitute typical members of sport clusters. LSF spatially non-transferable characteristics of a place and its economy (Dunning, 2001) provide an analytical grid to detect potential clusters, analyse their environment, and identify conditions supporting cluster development and sustainability. These LSF were classified into geo-economic, geographic, historical, political, socio-economic, and sport-related LSF. Ten different types of CLOR are identified as typical members of a sport cluster. Stakeholder theory (Freeman, 2010) guided the identification and classification of CLOR. In this process, we transferred the individual firm's view of stakeholders to a cluster's view of stakeholders. Stakeholders of a sport cluster are defined as all organisations that have an interest in the performance of the sport cluster, either in whole or in part.

The remainder of the article is structured as follows. The next section reviews literature on sport clusters, LSF, and those aspects of stakeholder theory relevant to clusters. The third section presents the research design and methods for data collection and analysis. The fourth section presents results and findings. The final section discusses the findings, limitations, implications, and further research opportunities.

\section{Theoretical Framework}

\section{From Marshallian Industrial Districts to Sport Clusters}

The economic geographer Marshall (2000) combined sociological and economic perspectives in his pioneering work on localised industries. Marshall (2000) explains that localised 
industries develop traditionally due to particular physical conditions of a location. In this traditional view, tangible aspects of a location such as climate, landscape, natural infrastructure, and resources are prominent. However, Marshall (2000) also takes into account the socio-cultural factors of a location such as the character of local residents, their skills and knowledge, the ability to pass it on, their political, legal and social institutions, and their spirit for entrepreneurship and free trade. These socio-cultural factors are important for not only a localised industry's development but more so for its success and longevity. When a location provides favourable conditions for the establishment of a particular industry, it is likely that a simple industrial agglomeration turns into an industrial district (Marshall, 2000). Industrial districts are more than just a concentration of firms producing the same or similar products. Industrial districts are characterised by the division of labour between local enterprises, strong product specialisation, high interdependency of the firms, close intrasectoral and interorganisational networks, high level of informal and formal cooperation, and high vertical and horizontal integration of the entire value chain (Asheim, 2000; Bellandi, 1996, 2002).

A variety of terms describe this phenomenon - innovative milieu, network, or cluster. The innovative milieu concept focuses on innovation-related aspects within Marshallian industrial districts (Camagni, 1993). Central characteristics of an innovative milieu are similar to the ones of an industrial district. There is extensive division of labour. Learning processes take place within the milieu through 'learning-by-doing' and 'learning-by-using'. There is high labour mobility within the innovative milieu but not external to it. Economies of scale and other group advantages occur similarly to those in large corporations but without reducing flexibility of the individual firms. Dense industrial input-output relations facilitate a certain industrial culture and atmosphere. Transaction costs are reduced due to spatial proximity. Increased entrepreneurship and innovation capabilities and activities are further positive 
outcomes (Camagni, 1995). The innovative milieu differs from an industrial district because it incorporates innovation capabilities, in addition to the efficiency of localised economies.

A cluster is a 'geographically proximate group of interconnected companies and associated institutions in a particular field, linked by commonalities and complementarities' (Porter, 2008, p. 215). Cluster membership is diverse. A cluster can include specialised suppliers, service providers, firms in related industries, and associated institutions such as universities, standard agencies, and trade associations. CLOR may compete and cooperate at the same time. They may operate in the same or similar industries. Cluster dynamics affect competition and competitiveness of CLOR in three principal ways: increased productivity, innovation, and augmented entrepreneurship and new business formation (Porter, 1998). A cluster provides 'large organisation' advantages for CLOR such as scale economies, specialty know-how, and access to innovations. However, CLOR can also maintain their flexibility and individuality as formal agreements are uncommon (Porter, 1998).

Reflecting their ubiquity, clusters have been studied in a variety of countries and industrial contexts (Porter, 1998). Clusters occur in developing or advanced economies, high tech or traditional industries, manufacturing or service industries, on supranational, national, regional, or local level (Porter, 2008). CLOR are not only vertically integrated (e.g., suppliers, manufacturers, and customers), but also horizontally integrated through, for example, manufacturers of complementary products and providers of infrastructure or services. Furthermore clusters might comprise institutions such as governmental bodies, universities, agencies, and industry/ professional associations. The key difference between clusters and previous models of localised industries is the holistic consideration and analysis of economic agglomerations and their influence on competition and cooperation. Previous studies on cluster theory and related theories (i.e., industrial district, innovative milieu) focus on particular aspects of clusters or particular types of clusters. 
The cluster concept has been applied to sport and sport-related industries. Some studies have been conceptual (Hillairet, 2005; Shilbury, 2000), but most is empirical research in which sport clusters are mapped, analysed, or used as an empirical context for certain research questions (Chetty, 2004; Kellett \& Russell, 2009; Parker \& Beedell, 2010; Richard, 2007; Sarvan et al., 2012; Stewart et al., 2008; Viljamaa, 2007). We specifically build on Shilbury (2000) who proposes sport clusters as future sport delivery systems. Stewart et al. (2008) investigate the surfing industry in Torquay, Australia. They explore the relevance of Porter's cluster model to Torquay's surf industry. Others study skateboarding in Australia and the relevance of clusters to new sport delivery systems (Kellett \& Russell, 2009). Other sportrelated empirical cluster studies are concerned with yacht building clusters in New Zealand (Chetty, 2004) and Turkey (Sarvan et al., 2012), Southern England's horseracing industry (Parker \& Beedell, 2010), North Carolina's (USA) motorsport cluster (Viljamaa, 2007), and the sport equipment cluster in the region of Rhônes-Alpes (France) (Richard, 2007).

Shilbury (2000) argues sport clusters are a particular form of clusters and analyses the development of different localised sport industries. The notion of the sport industry as one generic industry is contrasted with the development of separate sport-by-sport clusters formed around one sport or multiple sports. Shilbury (2000) argues that the sport industry consists of multiple industry sectors rather than one generic industry (Chadwick, 2009). Sport clusters represent the agglomeration of similar or overlapping sport industry sectors. The sport equipment industry can be divided into sectors according to disciplines (e.g., rugby, sailing), equipment (e.g., racket, board), or environment (e.g., outdoor, indoor). Shilbury (2000) proposes that sport clusters combine different sport industry sectors either with a common interest in the same sport (e.g., sailing) but providing different products and services, or with a common interest in the same product (e.g., rackets) but with regards to different sports. 
Shilbury (2000) calls for research examining the changing sport industry structures, especially interactions between industries and organisations. This is to enhance the understanding of clusters and competition, both in sport and non-sport settings. However, few scholars have focused on the issues raised. On this basis we propose the following research question: What is a sport cluster? The second research question seeks to understand the conditions within which clusters develop and sustain themselves: What location-specific factors affect sport cluster development and sustainability? The third research question asks: Which organisations are in a sport cluster? To answer this question we are guided by stakeholder theory (Freeman, 2010) and we develop a cluster member typology.

\section{Location-Specific Factors}

Location-specific factors have been studied in research on the internationalisation of companies (Dunning, 1980; Rugman, 2009). Ownership of or accessibility to resources, capability to internalise those resources, and the attractiveness of exploiting owned and internalised resources in other than the home location are key determinants for international production decisions of companies (Dunning, 1980). Rugman (2009) synthesises Dunning's paradigm into the model of country-specific versus firm-specific advantages. The ownership and internalisation of resources is synthesised in firm-specific-advantages while locationspecific factors are translated as country-specific advantages. Location decision of firms depend on their ability to utilise firm-specific advantages in a more advantageous manner in a foreign country than in the home country in conjunction with country-specific advantages (Rugman, 2009).

Cluster theory and industrial district research are closely linked to the analysis of location decisions of firms, especially the analysis of firms' location decisions in industrial agglomerations. Cluster research is concerned with the investigation of industrial agglomerations, the reasons for their emergence, development, and sustainability. Cluster 
research has been applied to different socio-economic contexts, lending support to the argument that clusters are widespread (Lazzeretti, Sedita, \& Caloffi, 2014; Motoyama, 2008). However, this does neither explain how competitiveness can be achieved through agglomeration (Motoyama, 2008) nor identify the factors influencing their success or failure (Arthurs, Cassidy, Davis, \& Wolfe, 2009). This research addresses the question of how LSF support the emergence, development, and sustainability of clusters in the socio-economic context of sport. The analytical framework of LSF for sport clusters that is developed in this paper is inspired by previous research that argued the contribution of geo-economic factors (e.g., access to specialised labour and suppliers) and socio-economic factors (e.g., access to information and ideas via social relationships) of industrial agglomerations. These two sets of factors are complemented by inductively emerging themes during data analysis (e.g., sportrelated factors) (Gordon \& McCann, 2000). Also discussed is the extent to which CLOR exploit these LSF in combination with firm-specific factors.

\section{Stakeholder Theory and Clusters}

Stakeholders are 'those groups without whose support the organisation would cease to exist' (Freeman, 2010, p. 31). In short stakeholders have a particular interest in an organisation (Ansoff, 1987). Cluster research is closely intertwined with stakeholder theory. Clusters consist of agglomerations of horizontally and vertically interlinked firms and associated institutions in a particular field (Porter, 2008). These firms and organisations have a shared interest in the prosperity and advancement of their field. The cluster would cease to exist without the support of individual CLOR. Therefore the stakeholder concept is valid in the context of clusters when speaking of CLOR as stakeholders of the cluster.

Previous cluster research has used the term of stakeholders in the context of clusters as the organisations that have a shared interest in the prosperity of the respective cluster (Arthurs et al., 2009). Cluster stakeholders are also mentioned in the context of sport clusters 
(Shilbury, 2000). Sport cluster stakeholders are all industries, sellers, and buyers with an impact on a particular sport. Three levels of stakeholders are differentiated: those with the strongest interest in the sport, those with moderate interest in the sport, and those with least interest in the sport (Shilbury, 2000). This paper further investigates stakeholders in sport clusters and specifies different types of CLOR and their roles for the functioning of the sport cluster.

\section{Methods}

We use a single case study design (Eisenhardt, 1989; Yin, 2009). Case studies allow the development of testable, relevant, and valid theory (Eisenhardt, 1989). Cases studies are rich, empirical descriptions of real phenomena that typically utilise a variety of data sources (Yin, 2009). While some researchers argue for multiple cases to enhance generalisability, others argue that more depth is possible within single case studies (Eisenhardt, 1991). However, rather than searching for the ideal number of cases, it is more important to choose an appropriate number of cases with regards to how much is known about a phenomena and how much new information can be learned from one or several new cases (Eisenhardt, 1991). Given that sport clusters are still an under-researched topic, a single case study was utilised. While most case study research is used for inductive theory building (Eisenhardt, 1989), there are other possibilities for theorising from case study research (e.g., natural experiment, interpretive sensemaking, and contextualised explanation) (Welch, Piekkari, Plakoyiannaki, \& Paavilainen-Maentymaeki, 2011). We follow Eisenhardt's (1989) process of theory building from case study research but we employ a combination of methods for theorising from case research. Eisenhardt's (1989) steps for case study research are defining research questions, selecting a case, collecting data through multiple primary and secondary data sources, data processing through transcribing and report writing during data collection, within-case analysis through content and narrative analysis, comparison of data with 
literature, and theorising through interpretive sensemaking and contextualised explaining. Theorising from contextualised research is often regarded as the opposite of producing generalisable theory from hypotheses testing. Welch et al. (2011) challenge this argument and explain how context can be combined with causal explanation to develop theory. In this article we provide a thick and rich description of the case which allows interpreting and understanding of key characteristics and actors in one sport cluster through explaining observed phenomena (Welch et al., 2011).

We select the ocean racing cluster in Brittany, France (SAILBRIT). SAILBRIT incorporates around 120 organisations that employ approximately 1,000 employees. The financial turnover within SAILBRIT is estimated at $€ 130 \mathrm{M}$ (Eurolarge Innovation, 2012). The centre of the cluster is located in Lorient in Southern Brittany between Brest and Vannes, a coastal region spanning 186 kilometres (Eurolarge Innovation, 2012). The wider Brittany boating industry consists of 1,300 companies and has a €700M turnover (Tracogna, 2010).

\section{Data Collection}

Data collection occurred between November 2011 and November 2012. Consistent with best practice, different data sources were used: interviews, observations, and secondary data (Chetty, 2004; Yin, 2009). Seven informal explorative interviews were conducted with employees or other industry experts from five different CLOR. The interviews probed the interviewees' knowledge of the cluster and their experiences with other CLOR. Ten types of CLOR resulted from the explorative interviews - especially those with the cluster manager and secondary data. The cluster manager helped to identify and facilitate the participation of key players in semi-structured interviews. We interviewed at least two organisations per type of CLOR (except only one amateur organisation). In those categories that seemed more important (e.g., marine equipment firms), we interviewed more than two organisations. The snow-ball method - where participants identified potential participants - was also employed. 
Twenty-seven formal semi-structured interviews were conducted with top managers and managers or employees from research and development and marketing departments of 25 different CLOR. These organisations and individuals were identified as being primarily involved in the cluster. The semi-structured interview questions probed the organisations core business (e.g., Can you give me an overview of your organisation and its activities?), the role of LSF (e.g., If your organisation was to move to another location, what difference would that make to your organisation?), and the nature of their relationship with other CLOR (With which organisations/ firms in the cluster does your organisation have especially important relationships?; Why are these relationships important?; and, Can you describe the relationships between your organisation and others in the cluster?). The interviews were recorded and transcribed by the principal investigator. The transcripts were sent to interviewees for verification purposes. Over half (i.e., SAILBRIT 55\%) of participants confirmed or offered revisions of transcripts. The interviews provided about 24 hours recording and 434 pages of transcript. The principal investigator translated verbatim quotations from French to English which were verified by one co-author.

Out of the 34 interviews, 25 were conducted in-person, four interviews were conducted via videoconference, and five via telephone. The interviews were primarily conducted in French $(n=33)$ and partly in English $(n=1)$ and the average interview length was 50 minutes, ranging from 20 minutes to 110 minutes. Table 1 lists the CLOR interviewed, the assigned code, the number of employees, and the interviewee's position.

--- Insert Table 1 here. ---

In addition to the interviews, the principal investigator conducted eight observations at trade shows, sport events, product trials, professional seminars, and networking events. 
Observation outputs were notes, photographs, explorative interviews, advertisements, event programmes, and newspaper articles. The collected data were summarised in observation reports. Observations were conducted before, during and after interviews and were often an occasion to conduct explorative interviews. Results from explorative interviews were integrated in observation reports. Information from observations provided an overview of CLOR and their engagement in the cluster. Observations proved to be more efficient than contacting CLOR by mail or phone. Lastly, some observations provided us with direct evidence for investigated themes.

Secondary data were divided into organisational information and archival data. Organisational information included CLOR-authored presentations, brochures, catalogues, and websites. Archival data included sailing and boating specialist journals, industry reports, and publications in mainstream media.

\section{Data Analysis}

Data analysis was conducted after the completion of data collection, transcribing, and report writing. All primary and secondary data were imported into NVivo for thematic analysis. We identified and allocated themes to both the textual and visual data. All data were initially examined for any reference to LSF or any CLOR. Then, we conducted content and narrative analysis (Yin, 2009). Content analysis utilised frequency counts to organise data and make quotation retrieval easier. Based on Babiak and Thibault's (2009) approach we quantify our data in two ways. The first category is 'number of times a theme appears in data'. The other category is 'number of sources within each theme'. Narrative analysis was done through report writing using the thematic and content analysis to derive answers to our research questions (Berg \& Lune, 2012).

The coding system for the thematic analysis was developed deductively from the start but inductively complemented with emerging 'sub themes' under the predefined 'main 
themes' (LSF and CLOR) over several coding cycles (Miles, Huberman, \& Saldaña, 2014). Here we present only the final coding system. Each of the three research questions was deconstructed to define preliminary main themes and corresponding sub themes. To determine what constitutes a sport cluster the sub themes LSF and CLOR were identified. To identify the factors affecting sport cluster development and sustainability, the main theme was LSF. The sub themes were: geo-economic LSF, geographical LSF, historical LSF, political LSF, socio-economic LSF, and sport-related LSF. To identify the organisations within the cluster, the main theme was CLOR. The sub themes of CLOR were differentiated for sailing clusters and generic sport clusters and classified as for-profit organisations and not-for-profit organisations (refer Table 2).

--- Insert Table 2 here. ---

\section{Findings}

\section{Location-Specific Factors}

Results for LSF are presented first, followed by CLOR. LSF are spatially non-transferable characteristics of a place and its economy (Dunning, 2001). The six different types of LSF (presented in order of prominence) were: geo-economic, sport-related, socio-economic, political, geographical, and historical factors. For the most prominent LSF we provide exemplary, verbatim quotations (Table 3). The meaning of each quotation is explained in the text accompanying the table. The complementary quantitative findings are presented at the beginning of each LSF sub theme.

--- Insert Table 3 here. --- 
Geo-economic LSF relate to location, distribution, and spatial organisation of economic activities. Geo-economic LSF were referred to 174 times from 40 sources (30 interviews, three observations, five archival data, and two organisational information). A spatial analysis shows that most CLOR are located in the Southern part of Brittany, especially in the town of Lorient. For SAILBRIT, inclusion in the cluster is based on the firms' involvement in the cluster's core segment, the ocean racing industry. The activities of SAILBRIT firms are extremely diverse. The geo-economic structure of SAILBRIT is characterised by a large variety of small-to medium-sized enterprises and much fewer large multinational enterprises (GB2a) that are competitors or complementary to each other (GB3a).While many of these companies have been in the area for a long time, there is a constant flow of new and emerging companies that are attracted by the concentration of related CLOR (GB3b).

Spatial organisation means the co-location of CLOR. Professional sport organisations emphasised the importance of physical proximity (PS1). Marine service firms engaged as subcontractors for other CLOR consider their proximity to clients (e.g., professional racing teams) as extremely relevant (MS1a). Some marine service firms purposely came to SAILBRIT's central hub to re-locate or open a second office. Their aim was to benefit from the co-location with other CLOR, especially with professional racing teams and shipyards (MS3a).

Marine service firms are often the intermediaries that sell and instal marine equipment on clients' boats. Therefore, marine service firms desire close physical proximity to marine equipment firms and shipyards (MS5). Marine equipment firms confirm the importance of physical proximity. One participant spoke of the importance for close contact and exchange with professional racing teams (ME2a). Marine equipment firms need to establish and maintain direct contact with private clients, shipyards, and distributors (ME3a). 
Sport-related LSF relate to professional or non-professional sport factors in a particular location. Sport-related LSF were referred to 99 times from 33 sources (24 interviews, three observations, two archival data, and four organisational information). The high number of berths, marinas, and boat registrations in Brittany indicate a high level of sailing activities in the leisure segment which results in an increased local demand for marine goods. Sport events that attract amateur and professional sailors are another economic lever of SAILBRIT.

The presence of professional racing teams stimulates SAILBRIT. Though not originally the case, an increasing number of local firms rely upon sales in the ocean racing sector (GB1a). Though initially small, some of these firms have grown to medium-sized businesses. ME1 argues that SAILBRIT has developed because of professional racing teams (ME1a). The sailing cluster is home to numerous world-class sailors that contribute to the sailing industry and cluster (ME2b). Firms that are doing business with professional racing teams benefit from reputation gains and innovation/ technological developments (ME3b). Shipyards acknowledge local knowledge and resources especially in technology for ocean racing boats which stimulates collaboration (SY1). Especially marine equipment and service firms mention their dependence on professional sailing teams (ME4a)

The dependence of SAILBRIT on ocean racing teams is problematic for at least three reasons. Ocean racing teams depend upon sponsors and their financial support which can fluctuate (GB3c). Second, rules committees can change regulations that affect boat design and related equipment and hence the business of firms that depend on ocean racing teams as clients. Furthermore competition committees can decide to centralise the purchase of sporting equipment for a competition, and hence fewer firms from any location benefit.

Socio-economic LSF refer to economic activities affecting social processes and vice versa. Socio-economic LSF were referred to 82 times from 26 sources (24 interviews, one 
archival data, and one organisational information). Attitudes and perceptions of cluster stakeholders, especially governing bodies, had to change significantly to create a cluster centred on a sport and its economic activities (GB1b). Increased interest of the population in sailing activities fuelled an increase in the number of local enterprises and sport teams. Even though these enterprises are not the most profitable, they remain attractive for business buyers and investors because of their link to sport and people's passion about sport (GB2b).

The involvement of professional or non-professional sailing in the local community facilitated strong and trustful relationships between individuals working in different CLOR. Despite originating in sport, SAILBRIT benefits from those relationships because they were transferred into business within the cluster (GB3d). The passion for sport translates into passion for jobs and entrepreneurship in the cluster (ME5a). The notion of 'family' is used to describe the cluster (MS2a). Regular formal and informal exchanges underline the notion of family as well as embracing new firms. Interviews with marine equipment firms provide evidence for this phenomenon. The passion for the sport can be interpreted as an invisible link between cluster stakeholders which manifests itself through more friendly behaviour between CLOR when compared to other clusters (ME5b).

Political LSF are factors related to local politics, rules, legislation, and government decisions that impact on a cluster and CLOR. Political LSF were referred to 73 times from 22 sources (18 interviews, three archival data, and one organisational information). The key politically-driven measure for the development of SAILBRIT was the early construction of sailing marinas and other maritime infrastructure that attracted both professional and amateur sailors.

Geographical LSF refer to the cluster environment and determining conditions such as geography, topography, weather, and climate. Geographical LSF were referred to 43 times 
from 22 sources (21 interviews and one archival data). The most important geographical aspect is the proximity and access to water and relatively safe, year-round sailing conditions.

Historical LSF relate to events and persons that have influenced the development of the cluster in the past. Historical LSF were referred to 33 times appearing in 17 sources (16 interviews and one archival data). The duration of links between CLOR are sometimes measured in decades, rather than years which indicates persistence. It was often professional sailors who created these initial links.

\section{Cluster Organisations}

Cluster stakeholders have an interest in the performance of the sport cluster as a whole or parts of it (Freeman, 2010). Ten different types of CLOR were identified: shipyards, sailmaker/ rigging firms, marine equipment firms, marine service firms, media/ communication firms, naval architects, professional sport organisations, amateur organisations, governing bodies, and education/ research institutes. For those types of CLOR with prominent roles in the cluster we provide exemplary, verbatim quotations (Table 4). The source of each quotation is indicated using the abbreviations for interviews with different CLOR representatives provided in Table 1. Lowercase letters are added in alphabetical order if the same source is cited multiple times. The meaning of each quotation is explained in the following text.

--- Insert Table 4 here. ---

Shipyards are private, for-profit organisations that construct boats or boat hulls. Shipyards were referred to 130 times across 37 sources (27 interviews, five observations, three archival data, and two organisational information). Shipyards are central to SAILBRIT because of the varied expertise required for boat construction projects. Shipyard founders are 
often former professional sailors who are rooted in the territory, and hence have a personal interest in SAILBRIT (GB4).

Marine equipment firms as well as marine service firms refer to shipyards most often in the context of work relationships. Marine equipment and service firms might have a direct (e.g., supplier or subcontractor) or indirect relationship (i.e., through other CLOR) to shipyards. For example, a naval architect can design a part of the boat that is fabricated by the marine equipment firm. Similarly, a boat project manager coordinates the different firms involved in a boat-building project. The shipyard also brings together different marine equipment firms when they supply to the same project (ME2c).

Shipyards were one of the most visible CLOR at industry seminars and exhibitions. This visibility is another indicator of their centrality to the cluster. Governing bodies talk about shipyards as the organisation that bring together all other CLOR. They also refer to shipyards as a key partner for the professional ocean racing teams.

Professional Sport Organisations include non-profit and for-profit professional racing teams, semi-professional racing teams, and high performance training centres for young athletes or Olympic athletes. Reference was made to professional sport organisations 117 times from 27 sources (24 interviews, two observations, and one organisational information). It is important for marine equipment firms to be in close proximity to professional sport organisations because they work directly with the athletes, some of whom are involved in the product development process (ME3c). One participant made clear that the cluster only exists because of the presence of professional sport organisations (ME1b). The work with the professional teams puts marine equipment firms into contact with other CLOR (e.g., naval architects). A marine equipment firm might be hired to manufacture a component for the boat (e.g., keel). The firm must acquire the relevant technical information from the naval architect even though there is no contractual agreement between them. The professional 
team is the linking element. In another case, the links between a marine equipment firm and the professional team are also informal. For example, the marine equipment firm will provide free equipment but receive product feedback from the professional team (MS3b). The proximity and exchange between professional sport organisations and marine equipment firms create a very dynamic environment (ME6). For marine service firms' physical proximity to professional teams means high efficiency and flexibility to provide services around consulting, controls, research, distribution of specialised products, and installation of electronics and navigation devices (MS1b). Governing bodies recognise professional sport organisations as driving force of the cluster (GB3e).

Governing Bodies are organisations that control, influence, or regulate the cluster or parts of the cluster. Governing bodies were referred to 115 times across 31 sources (23 interviews, four observations, one archival data, and three organisational information). This type of CLOR includes local authorities, chambers of commerce, and other industry associations that execute a governing role on cluster stakeholders. We want to emphasise a particular governing body - the cluster governing body (CGB). The function of the CGB is to promote the interests of each CLOR and the cluster as a whole. CGB facilitates networking and collaborations between CLOR. However, not all clusters have a CGB.

We identify a CGB in SAILBRIT. CGB is funded by three different public authorities and membership fees of private members. It consists of five full-time employees and a director based in an office in the centre of SAILBRIT. They act independently but in collaboration with other governing bodies. The special role of the CGB becomes particularly evident at observations of industry and sport events. The CGB facilitates networking, collaborations, and joint representation of the cluster and its members. ME4 expresses confusion about the number and responsibilities of the different governing bodies (ME4b). 
However, ME5 acknowledges the support and initiative taken by governing organisations, especially by CGB (ME5c).

Marine service firms and media/ communication firms acknowledge the important role of governing bodies, especially the CGB (MS2b). This pertains to networking, collaboration, exchange, and accessing information and resources from other CLOR.

Marine Equipment Firms are for-profit organisations that design and/ or manufacture marine equipment. Marine equipment firms are referred to 100 times across 29 sources (20 interviews, six observations, two archival data, and one organisational information). They have links to other marine equipment firms as subcontractors or buyers/ suppliers of parts or accessories (ME5d). These relationships can go beyond simple supplierbuyer relationships to include product development (ME5e). GB1 explains that marine equipment firms are the driving force for innovation in the cluster (GB1c). Observations reveal the high participation rate of marine equipment firms in interorganisational meetings and initiatives. These include industry seminars and support for a joint promotional initiative at the Brittany stopover of an international offshore racing competition.

Other CLOR. Education/ research institutes are usually non-profit organisations that provide education services but they play also an important role as research partners in topics related to sailing (ME3d). They were referred to 65 times from 27 sources (20 interviews, five observations, one archival data, and one organisational information). Marine service firms are for-profit organisations that provide services around sailing for other CLOR but also for each other (MS1c). They were evoked 57 times in 20 sources (16 interviews, two observations, and two organisational information). Sailmaker/ rigging firms are specialised system suppliers that design and manufacture sail boat specific equipment such as masts, rigs, and sails. They are an important partners for shipyards but also for each other because they often produce complementary products (GB3f). Sailmaker/ rigging firms were referred to 55 times in 22 
sources (13 interviews, five observations, one archival data, and three organisational information). Naval architects are individual artisans or firms that are concerned with the conception and design of boats. Data referred 35 times to naval architects in 15 sources (13 interviews, one observation, and one organisational information). Marine media/ communication firms provide services or products specialised in maritime sports and were mentioned 15 times in 10 sources (five interviews, three observations, and two organisational information). Amateur organisations are usually non-for-profit organisations but can be forprofit organisations. These organisations bring together non-professional sailors at all levels. Data referred 10 times to amateur organisations in three sources (two interviews and one observation).

\section{Discussion and Conclusions}

\section{Overview of Findings}

This research proposes a framework to detect and analyse sport clusters. Hence, we discuss the relevance of the different elements - LSF and CLOR - with regards to the results from our case. A sport cluster is determined by different LSF. Geo-economic, socio-economic, and sport-related LSF appear most influential. Political, geographical, and historical LSF are less influential. On this basis we conclude that the LSF factors proposed originally, are all relevant, but to varying extents.

Ten different types of organisations were identified as typical CLOR in this sport cluster. Shipyards, professional sport organisations, governing bodies, and marine equipment firms are key to SAILBRIT. Education/ research institutes, marine service firms, sailmaker/ rigging firms, and naval architects appear to play less pivotal roles. Media/ communication firms and amateur organisations are less prominent in the data.

After having identified typical CLOR and LSF that determine development and sustainability of sport clusters, we now discuss the relationship between the two. We discuss 
the capacity of CLOR to combine their firm-specific advantages - ownership and internalisation of resources - with LSF, and hence their capacity to take advantage of LSF.

\section{LSF Findings}

Marine equipment and service firms are the CLOR most capable of combining firm-specific factors (e.g., specialised expertise, ideas for innovation) with geo-economic LSF. Participants from these CLOR provided many examples of how they benefit from co-location with professional sport organisations, shipyards, and sailmaker/ rigging firms. Physical proximity and non-bureaucratic access to clients are very important aspects for marine equipment and service firms because it enables them to provide their best products and services in the most efficient manner. Governing bodies refer to geo-economic LSF of SAILBRIT when they referred to the economic activity surrounding the professional ocean racing teams.

Marine equipment firms are very capable of exploiting sport-related LSF in the cluster. Marine equipment firms tend to be small-and medium-sized. They are often close to sailing sports because their owners/ staff also sail. Their smaller size permits them to act quickly and to anticipate clients' needs through regular interaction and visits to either shipyards or ocean racing teams. Marine equipment firms tend to be involved in ocean racing and amateur sport events as sponsor and supplier, but also on local or regional trade shows to present the cluster collectively.

Governing bodies leverage sport-related and socio-economic LSF in the cluster. CLOR are often unable to exploit sport-related and socio-economic LSF without the support and facilitation of governing bodies, notably the CGB. Sport-related and socio-economic LSF are leveraged through networking events, seminars, and CGB-initiated collaborations. An example is the jointly-funded presentation of CLOR's competencies during a professional ocean racing competition. 
Some but not all CLOR exploit LSF in conjunction with their firm-specific factors.

Overall geo-economic factors, sport-related, and socio-economic factors are mostly exploited by small-and medium-sized marine equipment and service firms and facilitated through governing bodies.

\section{CLOR Findings}

Shipyards have a strong position in the cluster. Marine equipment and service firms are often commercially dependent upon them. Interorganisational relationships between these different CLOR can be complex. A similarly strong position is occupied by professional ocean racing teams. These teams work often directly, or indirectly via the shipyard or naval architect with marine equipment and service firms and the sailmaker/ rigging firms. Governing bodies, notably the CGB, play a crucial intermediary role for marine equipment, service, and media/ communication firms to access shipyards and professional sailing teams. Marine equipment firms are also strongly interdependent amongst each other as they conduct mutual subcontracting or rely on each other's help in the urgent cases of clients' demands that cannot be fulfilled by one single firm.

\section{Implications for Researchers and Practical Relevance of the Findings}

The concept of sport clusters was evoked more than a decade ago. Without any further refinement this concept has been arbitrarily used in different studies. This research suggests a framework that takes sport cluster research onto a more consistent and rigorous scientific level. This is done by providing a definition that is applicable in different contexts and a consistent framework for the detection, analysis, and comparison of sport clusters. Sport clusters are geographical concentrations of interconnected organisations that provide different products or services related to a sport, professional and amateur sport entities, sport-related education/ research institutes, and governing bodies that exert control or influence over these organisations. All these sport CLOR are linked through different types of interorganisational 
linkages and behaviours. Sport clusters emerge from certain conditional LSF. The key differentiation of sport clusters from traditional clusters is the inclusion of sport-specific actors such as professional and amateur sport entities and sport-related LSF. Further research should test the suggested framework of sport clusters in other sports to validate or modify it. Furthermore it is suggested to test the sport cluster model in non-sport clusters (e.g., music) to identify generalisable elements which can enrich general cluster theory and nurture a discussion around a cluster typology.

The sport cluster framework has differing implications on the various cluster members. This research provides an analytical framework for governing bodies to investigate where and when cluster stimulating activities and investments make sense. An assessment of LSF and CLOR can inform decisions on whether governments and their agencies or industry bodies should engage in further cluster stimulating activities and investments. Further research could provide an analytical framework for cluster companies to analyse their interorganisational links and behaviours to create awareness about different forms of interorganisational links and behaviours and their potential benefits. CLOR' boundary personnel should be educated about different forms of interorganisational links and behaviours and conscious decisions and strategies should be taken by CLOR concerning their involvement in the cluster. Sport entities and education/ research institutes can use the sport cluster framework to analyse their environment and unveil opportunities of mutual benefit.

\section{Achievements, Limitations, and Further Research}

Conceptual studies on sport cluster have suggested similar frameworks (Hillairet, 2005; Shilbury, 2000) but not in the same depth and breath as the one suggested here. Hillairet (2005) investigates whether the innovative milieu concept can be applied in the sport sector. Factors such as solidarity, collective behaviour, efficient cooperation, and organised interaction are analysed. Hillairet (2005) concludes that the existence of innovative milieus in 
sport-related sectors is only a 'quasi-illusion'. He suggests the idea of 'micro-milieu innovators' which takes particularities of a location and sector into account but no concrete model is proposed. We consider these concerns in our model with the consideration of LSF. Shilbury's sport cluster model is limited to only sport organisations. The model developed in this research includes non-sport CLOR and factors influencing the development and sustainability of the cluster. Further research should take into account dynamics such as interorganisational relationships, networks, and behaviours in sport clusters.

The limitations of this research lie in the idiosyncrasy of a single case study research which is lessened by the relatively large data base for qualitative research in our case. Even though this research might neglect aspects occurring in other sport cluster cases it was necessary to conduct a detailed case study to investigate the concept of a sport cluster. We suggest comparative research and analysis of clusters in other sports and in other countries to further consolidate the sport cluster framework.

\section{Acknowledgements}

We wish to thank our interviewees and the cluster organisation Eurolarge Innovation for their participation in our study and we gratefully acknowledge the financial support of Paris-Sud University. 


\section{References}

Ansoff, H. I. (1987). Corporate strategy. London: Penguin Books (Original work published 1965).

Arthurs, D., Cassidy, E., Davis, C. H., \& Wolfe, D. (2009). Indicators to support innovation cluster policy. International Journal of Technology Management, 46(3), 263-279. doi: 10.1504/IJTM.2009.023376

Asheim, B. T. (2000). Industrial Districts: The Contributions of Marshall and Beyond. In G. L. Clark, M. P. Feldman \& M. S. Gertler (Eds.), The Oxford handbook of economic geography. Oxford: Oxford Universiy Press.

Babiak, K., \& Thibault, L. (2009). Challenges in Multiple Cross-Sector Partnerships. Nonprofit and Voluntary Sector Quarterly, 38(1), 117-143. doi: 10.1177/0899764008316054

Bellandi, M. (1996). Innovation and Change in the Marshallian Industrial District. European Planning Studies, 4(3), 357-368.

Bellandi, M. (2002). Italian Industrial Districts: An Industrial Economics Interpretation. European Planning Studies, 10(4), 425-437.

Berg, B. L., \& Lune, H. (2012). Qualitative Research Methods for the Social Sciences (8th ed.): Peachpit Press.

Camagni, R. P. (1993). Inter-Firm Industrial Networks: The Costs And Benefits of Cooperative Behaviour. Journal of Industry Studies, 1(1), 1-15.

Camagni, R. P. (1995). The concept of innovative milieu and its relevance for public policies in European lagging regions. Papers in Regional Science, 74(4), 317-340.

Chadwick, S. (2009). From outside lane to inside track: sport management research in the twenty-first century. Management Decision, 47(1), 191-203.

Chetty, S. (2004). On the crest of a wave: the New Zealand boat-building cluster. International Journal of Entrepreneurship and Small Business, 1, 313-329. doi:10.1504/IJESB.2004.005662

Chetty, S., \& Agndal, H. (2008). Role of Inter-organizational Networks and Interpersonal Networks in an Industrial District. Regional Studies, 42(2), 175-187. doi: 10.1080/00343400601142696 
Council of Europe Committee of Ministers. (2001). Recommendation No. R (92) 13 REV of the Committee of Ministers to Member States on the revised European Sports Charter 752 Meeting of the Ministers' Deputies / 16 May 2001: Council of Europe.

Dunning, J. H. (1980). Toward an eclectic theory of international production: some empirical tests. Journal of International Business Studies, 11(1), 9-31.

Dunning, J. H. (2001). The Eclectic (OLI) Paradigm of International Production: Past, Present and Future. International Journal of the Economics of Business, 8(2), 173-190.

Eisenhardt, K. M. (1989). Building Theories from Case Study Research. The Academy of Management Review, 14(4), 532-550.

Eisenhardt, K. M. (1991). Better stories and better constructs: the case for rigor and comparative logic. Academy of Management Review, 16(3), 620-627.

Eurolarge Innovation. (2012). Structure d'accompagnement et d'animation de la filière technologique de la course au large. Lorient: Eurolarge Innovation. Retrieved from http://www.eurolarge.fr/qui-sommes-nous/

Freeman, R. E. (2010). Strategic Management. A Stakeholder Approach. [GoogleBooks version]. Retrieved from http://books.google.de/books?hl=fr

Glass, M. R., \& Hayward, D. J. (2001). Innovation and Interdependencies in the New Zealand Custom Boat-building Industry. International Journal of Urban and Regional Research, 25(3), 571592. doi: $10.1111 / 1468-2427.00330$

Gordon, I. R., \& McCann, P. (2000). Industrial Clusters: Complexes, Agglomeration and/or Social Networks? Urban Studies, 37(3), 513-532. doi: 10.1080/0042098002096

Hillairet, D. (2005). Milieux innovateurs et filière sports-loisirs: essai d'application d'un paradigme techno-industriel du développement économique régional endogène. Paper presented at the XLIème Colloque de l'Association de Science Régionale de Langue Française, 5 - 7 septembre 2005, Dijon. Retrieved from http://w3.lisst.univ-tlse2.fr/

Kellett, P., \& Russell, R. (2009). A comparison between mainstream and action sport industries in Australia: A case study of the skateboarding cluster. Sport Management Review, 12(2), 66-78. doi: 10.1016/j.smr.2008.12.003 
Lazzeretti, L., Sedita, S. R., \& Caloffi, A. (2014). Founders and disseminators of cluster research. Journal of Economic Geography, 14(1), 21-43. doi: 10.1093/jeg/lbs053

Marshall, A. (2000). Principles of Economics (8th ed.). London, New York: Macmillan for the Royal Economic Society (Original work published 1890).

Miles, M. B., Huberman, A. M., \& Saldaña, J. (2014). Qualitative Data Analysis. A Methods Sourcebook (3rd ed.). London: Sage.

Motoyama, Y. (2008). What was new about the cluster theory? What could it answer and what could it not answer? Economic Development Quarterly, 22(4), 353-363.

Parker, G., \& Beedell, J. (2010). Land-based Economic Clusters and their Sustainability: The Case of the Horseracing Industry. Local Economy, 25(3), 220-233. doi: 10.1080/02690941003784275

Porter, M. E. (1998). Clusters and the new economics of competition. Harvard Business Review, November-December, 77-90.

Porter, M. E. (2008). Clusters and Competition. In M. E. Porter (Ed.), On Competition (pp. 213-303). Harvard: Harvard Business School Publishing Corporation.

Richard, G. (2007). Application du concept de milieu innovateur dans la filière sports-loisirs: Étude de cas dans l'industrie des articles des port rhônalpine. Revue d'Économie Régionale \& Urbaine, 2007/5, 831-859. doi: 10.3917/reru.075.0831

Rugman, A. M. (2009). Country Specific and Firm Specific Advantages. United Kingdom: Palgrave Macmillan.

Sarvan, F., Başer, G. G., Köksal, C. D., Durmuş, E., Dirlik, O., Atalay, M., \& Almaz, F. (2012). Network based Determinants of Innovation Performance in Yacht Building Clusters: Findings of the SOBAG Project. Procedia - Social and Behavioral Sciences, 58, 830-841. doi: 10.1016/j.sbspro.2012.09.1061

Shilbury, D. (2000). Considering Future Sport Delivery Systems. Sport Management Review, 3(2), 199-221.

Stewart, B., Skinner, J., \& Edwards, A. (2008). Cluster theory and competitive advantage: The Torquay surfing experience. International Journal of Sport Management and Marketing, 3(3), 201-220. 
Tracogna, A. (2010). International boat building clusters - Comparative analysis, forms of governance and development policies. Milano, Italy: AREA Science Park.

Tristão, H. M., Oprime, P. C., Jugend, D., \& da Silva, S. L. (2013). Innovation in Industrial Clusters: a Survey of Footwear Companies in Brazil. Journal of Technology Management \& Innovation, $8(3), 45-56$.

Viljamaa, K. (2007). Technological and cultural challenges in local innovation support activities emerging knowledge interactions in Charlotte's motor sport cluster. European Planning Studies, 15(9), 1215-1232. doi:10.1080/09654310701529169

Welch, C., Piekkari, R., Plakoyiannaki, E., \& Paavilainen-Mäntymäki, E. (2011). Theorising from case studies: Towards a pluralist future for international business research. Journal of International Business Studies, 42, 740-762.

Yin, R. K. (2009). Case Study Research: Design and Methods (4th ed.). Los Angeles, Calif.: Sage. 


\section{Tables}

Table 1: List of Interviews

\begin{tabular}{|c|c|c|c|c|}
\hline & Type of CLOR & Code & $\begin{array}{l}\text { No of } \\
\text { Employees }\end{array}$ & $\begin{array}{l}\text { Interviewees' } \\
\text { position }\end{array}$ \\
\hline \multicolumn{5}{|c|}{ Formal semi-structured intervie ws } \\
\hline $\mathbf{1}$ & shipyard & SY1 & 60 & General Director \\
\hline 2 & shipyard & SY2 & 45 & Production Director \\
\hline 3 & naval architect & NA1 & 4 & General Director \\
\hline 4 & naval architect & NA2 & 19 & General Director \\
\hline 5 & marine equipment firm & ME1 & 6 & General Director \\
\hline 6 & marine equipment firm & ME2 & 50 & Technical Manager \\
\hline 7 & marine equipment firm & ME3 & 25 & Technical Director \\
\hline 8 & marine equipment firm & ME4 & 3 & General Director \\
\hline 9 & marine equipment firm & ME5 & 400 & Marketing Director \\
\hline 10 & marine equipment firm & ME6 & 20 & $\begin{array}{l}\text { General Director/ } \\
\text { Innovation Manager }\end{array}$ \\
\hline 11 & sailmaker/rigging firm & SR1 & 49 & Global Director \\
\hline 12 & sailmaker/rigging firm & SR2 & 30 & General Director \\
\hline 13 & sailmaker/rigging firm & SR3 & 49 & R \& D Engineer \\
\hline 14 & marine service firm & MS1 & $1-3$ & General Director \\
\hline 15 & marine service firm & MS2 & 13 & General Director \\
\hline 16 & marine service firm & MS3 & $2-3$ & General Director \\
\hline 17 & marine service firm & MS4 & 5 & Innovation Manager \\
\hline 18 & media/communication firm & $\mathrm{MC} 1$ & 12 & General Director \\
\hline 19 & media/communication firm & MC2 & 16 & General Director \\
\hline 20 & professional sport organisation & PS1 & 13 & Innovation Manager \\
\hline 21 & professional sport organisation & PS2 & 16 & $\mathrm{R} \& \mathrm{D}$ Engineer \\
\hline 22 & education/research institution & ER1 & 900 & $\begin{array}{l}\text { Technology } \\
\text { Transfer Engineer }\end{array}$ \\
\hline 23 & education/research institution & ER2 & N/A & Director \\
\hline 24 & governing body & GB1 & 5 & General Manager \\
\hline 25 & governing body & GB2 & 2 & $\begin{array}{l}\text { Director for nautical } \\
\text { sector }\end{array}$ \\
\hline 26 & governing body & GB3 & 5 & Director \\
\hline 27 & amateur organisation & $\mathrm{AO} 1$ & 2400 & Water Sport \\
\hline & & & & Consultant \\
\hline \multicolumn{5}{|c|}{ Explorative interviews } \\
\hline 28 & sailmaker/rigging firm & SR4 & 49 & R \& D Engineer \\
\hline 29 & marine service firm & MS5 & 13 & $\begin{array}{l}\text { Commercial } \\
\text { Assistant }\end{array}$ \\
\hline 30 & media/communication firm & MC3 & N/A & Director \\
\hline 31 & marine equipment firm & ME7 & 20 & $\begin{array}{l}\text { Apprentice/ R\&D } \\
\text { Manager }\end{array}$ \\
\hline 32 & governing body & GB4 & 5 & Director \\
\hline 33 & governing body & GB5 & 5 & Director \\
\hline 34 & governing body & GB6 & 5 & Director \\
\hline
\end{tabular}


Table 2: Typology of CLOR in Sport Clusters

\begin{tabular}{lll}
\hline Gene ric type of CLOR & Sailing-specific CLOR & Code \\
\hline core equipment manufacturer & shipyard & SY \\
systems supplier & sailmaker/rigging firm & SR \\
accessory supplier & marine equipment firm & ME \\
services/consulting firm & marine service firm & MS \\
media/communication firm & marine media/communication firm & MC \\
designer/architect & naval architect & NA \\
professional sport organisation & "-" & PS \\
amateur organisation & "-" & AO \\
governing body & "-" & GB \\
education/ research institute & "-" & ER \\
\hline \multicolumn{1}{c}{ profit } & & \\
\multicolumn{1}{c}{ non-proft } & &
\end{tabular}


Table 3: Location-specific Factors of Sport Clusters

\begin{tabular}{|c|c|c|}
\hline Coded theme & Source & Verbatim quotation refe renced \\
\hline $\begin{array}{l}\text { Geo-economic } \\
\text { factor }\end{array}$ & GB2a & $\begin{array}{l}\text { 'It is not obvious to know who is part of the cluster and who is not because there are so } \\
\text { many differents professions. There is a extrem large spectrum of professions and of know- }\end{array}$ \\
\hline $\begin{array}{l}\text { Geo-economic } \\
\text { factor }\end{array}$ & GB3a & $\begin{array}{l}\text { 'So, [SAILBRIT], it is really what you call a cluster, that means there are small enterprises } \\
\text { that are competitors or complementary. So, they build a part of the boat but they can also } \\
\text { be competitors. There are several that do the same job.' }\end{array}$ \\
\hline $\begin{array}{l}\text { Geo-economic } \\
\text { factor }\end{array}$ & GB3b & $\begin{array}{l}\text { 'However, the attraction factor that is now represented by Southern Brittany and Lorient } \\
\text { for the new enterprises [is high]. There are firms that establish themselves here because } \\
\text { they understand that the concentration of enterprises that is here is attractive. In saying this, } \\
\text { if I am here and I need this competence, I can find it just next door, even if I don't know it. }\end{array}$ \\
\hline Geo-economic & PS1 & 'So, that is for sure if you are not very close - geographical proximity is very important.' \\
\hline
\end{tabular}

factor

Geo-economic MS1a 'Nevertheless, it is true that this proximity here that we can have with the professional factor ocean racing teams, we would loose it, it would be without doubt a bit problematique to continue working together and also to offer them some innovative solutions.'

Geo-economic MS3a 'Yes, we have a direct contact with the clients here. Many skippers are based here and factor teams also. So, in fact, the teams or skippers or the people that work for the team come very easily, they take products to make trials, to test them, etc. That is something that would not have been possible if we were based somewhere else, in fact. It would limit us already in terms of our relationships with direct client base.'

Geo-economic MS5 'Yes, it was because of the proximity to our clients, and then we have everythig here. We factor also work with shipyards. So, we supply material, we install material. So, it's really the proximity. That's why we are more reactif [being based here].'

Geo-economic ME2a 'Because we are close, that means that me, I travel regularly, I will go on the boat with the factor skipper, there are permanent exchanges and the fact of being close is interesting.'

Geo-economic ME3a '... we are also very much implanted in the territory with our clients from pleasure-boating factor which are not clients from racing, also with shipyards, stores, etc. We are even in contact direct with private clients. It happens very often that we go to see the boat if there is a problem or if they need some advice.'

Sport-related GB1a 'From that point we have analysed the fact of having professional ocean racing teams in factor Lorient that stimulated innovation in local enterprises. This local enterprises were originally not all service providers for ocean racing. They could be equipment manufacturer. Their sepciality was not necessarily in ocean racing in the beginning but the racing stables and the racing boats that were implanted in Lorient went to see these companies, which were rather small companies, and asked them for innovation. They stimulated these enterprises towards innovation and towards ocean racing.'

Sport-related MEla 'But the cluster, geographically it is here because it is here where you find essentially the factor racing boats, the racing teams, the racing stables, they are all based here essentially though.'

Sport-related ME2b 'However, we have many grand sailors who have contributed that the sector here factor developed importantly.'

Sport-related ME3b 'But the ocean racing, that is also for the image and to progress as well. We will talk about factor it maybe later but we use our implantation in the ocean racing for the image and to progress, to make innovation. But our main target, our main business target remains the leisure-boating, the boats that we see here, the normal boats.'

Sport-related SY1 'For example in France, there is a know-how for "offshore" boats, for the Volvo [Ocean factor Race], the Vendée Globe, the multihulls and things like that. That is something very specific that makes us wanting to work together because the technology is there.'

Sport-related ME4a 'It is true that a big part of our activity is based around ocean racing and around the factor professional teams.'

Sport-related GB3c "They [the ocean race teams] know very well that the ocean racing sector is dependant on factor sponsors. They know that everything that develops in the area of ocean racing has a economic value and hence, they think already about the future of the ocean racing team at mid-term.'

Socio-economic GB1b 'The local vision about the enterprises has changed. At first, we have understood that there factor is an economic reality around the ocean racing which was not at all perceived before. We realised that there was an activity which could be perennial.'

Socio-economic GB2b 'There are other sectors which are much more profitable than this one. In spite of factor everything the sector is attractive. I see a lot of buyers of businesses that come to see me today and that wish to buy a shipyard. They have completely different profiles.'

Socio-economic GB3d 'Very good and passionated sailors have created technological companies in a limited area factor which is also the area where they sail. So, there is already this population of enterprises which are technical firms developed by these sailors. [...] So they [the enterprises] are geographically close and the people all know each other. Originally they all know each other. [...] They were in the same teams. That is the key success factor.'

Socio-economic ME5a 'I think that is fairly true in the yachting, because it is a world of passionates and the people factor want to move forward. I think if we had the same thing in the automobile world, the people would be much more interested in rentability and profit.'

Socio-economic MS2a 'It is a family, you can say, it is the "Silicon Valley" of sailing, here. And that makes that we factor have even the same language, we will speak of the same thing.'

Socio-economic ME5b 'So, what I wanted to say is that we have an attitude that goes with our size. That means factor we are much more friendly. That means indeed there is this citizenship behaviour. That does not mean to be disinterested though, we have to make a living, but there is even though this atmosphere in the yachting which is much more friendly and in fact there are people that say that have it at their heart that the [sport] project works.' 
Table 4: Cluster Organisations

\begin{tabular}{|c|c|c|}
\hline Coded theme & Source & Verbatim quotation refe renced \\
\hline Shipyard & GB4 & $\begin{array}{l}\text { 'Most of the big ocean race shipyards in the ORCB have been established and developed } \\
\text { by sailors from the region that are engaged in the sport of sailing and wanted to improve } \\
\text { sailing performance in their home region, Brittany' }\end{array}$ \\
\hline Shipyard & ME2c & $\begin{array}{l}\text { '[...] we work with ship yards, like [name of ship yard] and sometimes with architect } \\
\text { offices.' }\end{array}$ \\
\hline Professional sport & ME3c & $\begin{array}{l}\text { 'That are the teams. We usually work with the person responsible for technology in the } \\
\text { team.' }\end{array}$ \\
\hline Professional sport & ME1b & $\begin{array}{l}\text { 'But the cluster, geographically it is here because it is here where you find essentially the } \\
\text { racing boats, the racing teams, the racing stables, they are all based here essentially } \\
\text { though.' }\end{array}$ \\
\hline Professional sport & MS3b & 'We let the team try it and then, we have a new product launched which is innovative.' \\
\hline Professional sport & ME6 & $\begin{array}{l}\text { 'The interest of Southern Brittany, that is on one hand that we have a breeding ground for } \\
\text { all the sailors and skippers close by and this is very dynamique }[\ldots] \text { ' }\end{array}$ \\
\hline Professional sport & MS1b & $\begin{array}{l}\text { 'MS1, that is a consulting firm for maritime expertise speaking broadly, close to its clients, } \\
\text { I'd say, which are diverse enough, that can be athletes of an ocean race team }[\ldots] \text { ' }\end{array}$ \\
\hline Professional sport & GB3e & $\begin{array}{l}\text { '[...] the more race teams there are and the more they are spread out in the territory, the } \\
\text { better is it }[\ldots] \text { The more boats are spread on the coastline the more likely it is that there is } \\
\text { a capacity to create enterprises around race stables as long as they stay in Brittany }[\ldots] \text { ' }\end{array}$ \\
\hline Governi & ME4b & $\begin{array}{l}\text { 'There are many organisations like that which stand a bit on each other's fe } \\
\text { never know really whom to ask or there are no ressources that could be pu }\end{array}$ \\
\hline Governing body & ME5c & $\begin{array}{l}\text { 'We were the only ones at first and then the whole area just sprung up like mushrooms } \\
\text { thanks to the efforts made by [names of several GBs]. It's the agency for economic } \\
\text { development created by organisations like [name of CGB] that accompanies enterprises, } \\
\text { especially small innovative enterprises to help them to register a patent for their innovation. } \\
\text { They accompany small firms and help them to grow.' }\end{array}$ \\
\hline Governir & MS2b & $\begin{array}{l}\text { 'Yes, I also wanted to say that one thing which is good here in Lorient is that there is [name } \\
\text { of CGB], [name of other GB], organisations that take care of it [the cluster], with very } \\
\text { competent people like [name of CBG director and other], and all that. That are people that } \\
\text { do something and that are paid for that. They juste connect people with each other.' }\end{array}$ \\
\hline $\begin{array}{l}\text { Marine equipment } \\
\text { firm }\end{array}$ & ME5d & $\begin{array}{l}\text { 'For the remaining products that we distribute we have partnership agreements with big } \\
\text { specialised brands.' }\end{array}$ \\
\hline $\begin{array}{l}\text { Marine equipment } \\
\text { firm }\end{array}$ & ME5e & $\begin{array}{l}\text { 'That means we give them [marine equipment firm] a specification sheet. They develop the } \\
\text { product for us.' }\end{array}$ \\
\hline $\begin{array}{l}\text { Marine equipment } \\
\text { firm }\end{array}$ & GB1c & $\begin{array}{l}\text { No, it is not necessarily the boats, initially when we saw the cluster arriving, it was much } \\
\text { more the equipment than the boats in themselves, so rigging and deck material, electronic } \\
\text { equipment, equipment for the life on board. [...] It is more in the equipment and everything } \\
\text { that equips the hull where we have seen a race in innovation.' }\end{array}$ \\
\hline $\begin{array}{l}\text { Education/ } \\
\text { research institution }\end{array}$ & ME3d & 'So, in fact, we have been working with the unviersities of Brittany for 20 years now.' \\
\hline $\begin{array}{l}\text { Marine service } \\
\text { firm }\end{array}$ & MS1c & $\begin{array}{l}\text { 'Otherwise, it is important to know, I think, that I work a lot with other freelancers like } \\
\text { myself who are mainly maritime experts.' }\end{array}$ \\
\hline $\begin{array}{l}\text { Sailmaker/ rigging } \\
\text { firm }\end{array}$ & GB3f & $\begin{array}{l}\text { 'Another example are the projects that develop amongst complementary but not competing } \\
\text { equipment suppliers. If you take the sailmaker [name] and the mastmaker [name] for } \\
\text { example. They [...] wanted to develop an innovative product with using each others } \\
\text { knowledge that would allow them to enter the cruise market for self-furling booms.' }\end{array}$ \\
\hline
\end{tabular}

